\title{
Pengaruh Partisipasi Penyusunan Anggaran Pada Kinerja Aparat Pemerintah Dengan Komitmen Organisasi Sebagai Variabel Pemoderasi
}

\author{
Tri Andriyani ${ }^{1}$ \\ I G. A. M. Asri Dwija Putri \\ ${ }^{1,2}$ Fakultas Ekonomi dan BisnisUniversitasUdayana (Unud), Bali, Indonesia \\ e-mail: andriiyaniiay30@gmail.com
}

\begin{abstract}
ABSTRAK
Populasi dalam penelitian ini adalah pejabat yang berwenang dalam penganggaran yaitu 37 OPD di Kabupaten Badung. Responden penelitian ini berjumlah sebanyak 121 responden. Teknik analisis data penelitian ini menggunakan MRA. Vvariabel partisipasi penyusunan anggaran berpengaruh positif pada kinerja aparat pemerintah daerah dengan nilai koefisien partisipasi penyusunan anggaran $\left(\mathrm{X}_{1}\right)$ sebesar 0,342 dengan tingkat signifikansi 0,000 yang nilainya lebih kecil dari taraf nyata yaitu 0,05 . Variabel komitmen organisasi memperkuat pengaruh partisipasi penyusunan anggaran pada kinerja aparat pemerintah daerah, nilai koefisien interaksi partisipasi penyusunan anggaran dengan komitmen organisasi $\left(\mathrm{X}_{1} \mathrm{X}_{2}\right)$ sebesar 0,281 dengan tingkat signifikansi sebesar 0,000 . Dengan nilai $\mathrm{R}^{2}$ sebesar 0,766 yang berarti sebesar 76,6\% variasi kinerja aparat pemerintah daerah mampu dijelaskan variabel partisipasi penyusunan anggaran, dan dengan komitmen organisasi sebagai variabel moderasi.

Kata kunci: Penyusunan anggaran, kinerja aparat pemerintah daerah, organisasi perangkat daerah
\end{abstract}

\begin{abstract}
The population in this study were officials who were authorized in budgeting, namely 37 OPDs in Badung Regency. This study amounted to 121 respondents. The data analysis technique of this research uses MRA. The variable budgeting participation has a positive effect on the performance of local government officials with the budgeting coefficient participation value (X1) of 0.342 with a significance level of 0.000 whose value is smaller than the real level of 0.05. Organizational commitment variable strengthens the influence of budgeting participation on the performance of local government officials, the interaction coefficient value of budgeting participation with organizational commitment (X1X2) is 0.281 with a significance level of 0.000. With a value of $R^{\wedge} 2$ of 0.766 , which means that $76.6 \%$ of the variation in performance of local government officials is able to explain the variable budgeting participation, and with organizational commitment as a moderating variable.

Keywords: Budgeting, performance of local government apparatus, regional apparatus organizations
\end{abstract}

\section{PENDAHULUAN}

Perkembangan perekonomian saat ini, menuntut adanya perubahan dan menyebabkan adanya pergeseran pemikiran yang kompleks di segala bidang. Salah satu perubahan tersebut adalah konsep otonomi daaerah yang menuntut adanya pemberian kewenangan yang lebih besar (desentralisasi) kepada daerah 
pada tingkatan kabupaten/kota, terutama dalam pelaksanaan pembangunan dan memberikan kebebasan serta keleluasaan kepada pemerintah daerah untuk menjalankan pemerintahannya.

Pemerintah daerah dituntut untuk memberikan pelayanan kepada masyarakat dengan menerapkan asas-asas pelayanan publik seperti transparansi, akuntabilitas, partisipatif, kesamaan hak, keseimbangan hak, serta kewajiban. Upaya pemerintah daerah untuk meningkatkan kualitas pelayanan publik terhadap masyarakat terus dilakukan. UU 23 Tahun 2014 tentang Pemerintah Daerahdikeluarkan untuk menggantikan UU 32 Tahun 2004 yang sudah tidak sesuai lagi dengan perkembangan keadaan, ketatanegaraan, dan tuntutan penyelenggaraan pemerintah daerah, dan diperkuat dengan PP No 8 tahun 2006 tentang pelaporan keuangan dan kinerja instansi pemerintah menyatakan bahwa dalam pelaporan keuangan berisi informasi mengenai kinerja instansi pemerintah.

Penilaian kinerja terhadap organisasi publik digunakan sebagai alat untuk mengevaluasi kinerja pada periode yang sebelumnya, untuk digunakan sebagai dasar penyusunan strategi perusahaan selanjutnya. Sebagai salah satu implementasi dari akuntabilitas kinerja pemerintah, maka dilaksanakan kewajiban pertanggungjawaban yang dimulai dari proses perencanaan, penyusunan dan pelaksanaan atas tugas dan fungsi pemerintah dalam mewujudkan visi dan misi serta tujuan yang telah ditetapkan.

Berdasarkan hasil pemeriksaan kinerja oleh Badan Pemeriksa Keuangan (BPK) semester II tahun 2017, mengungkapkan 2.008 temuan yang memuat 2.265 permasalahan senilai Rp 1,60 miliar, 6 permasalahan ketidakefisienan, 2.254 
permasalahan ketidakefektifan senilai Rp 524,68 juta, 2 permasalahan kerugian senilai Rp 11,20 juta, dan 2 permasalahan kekurangan penerimaan senilai Rp 1,63 miliar. Atas permasalahan kekurangan penerimaan, telah dilakukan penyetoran selama proses pemeriksaan ke kas pemda/BUMDsebesar Rp 631,37 juta (BPK, 2017). Hasil pemeriksaan BPK mencerminkan masih adanya permasalahan kinerja pemerintah dalam pemeriksaan kinerja tahun 2017 oleh karena itu kinerja aparat pemerintah daerah masih menarik untuk diteliti.

Secara umum, kinerja merupakan prestasi yang dicapai oleh organisasi dalam periode tertentu. Ukuran kinerja suatu organisasi sangat penting, guna evaluasi dan perencanaan masa depan. Sistem pengukuran kinerja diharapkan dapat mempengaruhi hasil kerja dari pemimpin organisasi yang dalam hal ini adalah kinerja aparat pemerintah daerah. Seseorang yang memegang posisi manajerial/atasan diharapkan mampu menghasilkan suatu kinerja manajerial yang tinggi (Pariono dan Wirawati, 2018).

Setiap organisasi termasuk pemerintah pusat maupun daerah dalam menjalankan tugasnya wajib mempunyai rencana yang matang untuk mencapai hasil yang maksimal. Rencana-rencana tersebut disusun secara baik dan selanjutnya dipakai sebagai pedoman dalam setiap langkah pelaksanaan tugas negara. Rencana pemerintah yang disusun dalam bentuk anggaran dan akan dijadikan pedoman pada saat melaksanakan tugas. Anggaran merupakan rencana keuangan masa depan, rencana tersebut mengidentifikasi tujuan dan tindakan yang diperlukan untuk mencapainya (Hansen dan Mowen, 2011: 424). Dalam anggaran akan dapat dilihat seberapa besar fungsi pemerintah dan faktor-faktor 
apa saja yang dapat mempengaruhinya dalam melaksanakan berbagai urusan pemerintahan. Penyusunan anggaran pada organisasi sektor publik dapat membantu mewujudkan akuntabilitas, karena anggaran dapat dijadikan standar atas kegiatan atau pengukuran kinerja pada organisasi sektor publik.

Keberhasilan dalam proses penyusunan anggaran salah satunya dapat dipengaruhi oleh sikap dan perilaku pihak yang terlibat dalam proses penyusunan anggaran(Ayunda dan Alit, 2016). Keterlibatan dan pengaruh bawahan terhadap pengambilan keputusan dalam proses penganggaran merupakan faktor utama untuk membedakan antara anggaran partisipatif dan nonpartisipatif (Rokhman, 2017). Anggaran partisipatif akan meningkatkan pelaksanaan partisipasi, aspirasi, dan motivasi yang akhirnya akan membawa efek positif pada kinerja organisasi. Proses penyusunan anggaran merupakan suatu kegiatan penting, karena anggaran akan memberikan dampak fungsional dan disfungsional terhadap sikap dan perilaku anggota organisasi yang terlibat dalam proses penyusunannya. Terjadinya dampak disfungsional dapat dicegah yakni dengan memberikan bawahan dalam hal ini pegawai atau karyawan untuk berpartisipasi dalam proses penyusunan anggaran (Silmilian, 2013).

Partisipasi anggaran merupakan tingkat seberapa jauh keterlibatan dan pengaruh individu didalam menentukan dan menyusun anggaran yang ada dalam divisi atau bagiannya. Partisipasi penyusunan anggaran merupakan metode yang paling baik dalam penyusunan anggaran, karena semua komponen yang ada dalam organisasi ikut terlibat dalam penyusunan anggaran (Yanti, 2016).Proses penyusunan anggaran menekankan pada pendekatan Buttom-up Planning, yang 
menyatakan bahwa bawahan diberi kesempatan untuk berpartisipasi dalam proses penyusunan anggaran karena menurutnya partisipasi dalam penyusunan anggaran diyakini dapat meningkatkan kinerja aparat pemerintah daerah. Dalam penyusunan anggaran diperlukan komunikasi antara atasan dan bawahan untuk saling memberikan informasi disamping dapat memberikan kesempatan memasukkan informasi lokal karena bawahan lebih mengetahui kondisi langsung pada bagiannya. Dengan partisipasi, akan terjadi mekanisme pertukaran informasi yang membuat manajer akan memperoleh informasi yang relevan dengan kerjasama (Wiguna dkk., 2017). Informasi tersebut memungkinkan pemahaman yang lebih baik tentang tugas yang akan dilakukan, sehingga diharapkan kinerja aparat pemerintah akan meningkat.

Penelitian mengenai hubungan partisipasi penyusunan anggaran pada kinerja aparat pemerintah daerah merupakan penelitian yang masih banyak diperdebatkan hingga sekarang.Penelitian empiris tentang partisipasi penyusunan anggaran terhadap kinerja aparat pemerintah telah banyak dilakukan oleh Kenis (1979), Brownell (1982), Brownell dan Mccinnes (1986), Fruscot dan Shearon (1991), Utama dan Rohman (2013), Saraswati (2015), Tarigan (2015),Zein (2016),Ayunda dan Alit (2016), Widya dan Mahendra (2018)mengenai pengaruh partisipasi penyusunan anggaran pada kinerja menemukan hasil bahwa partisipasi penyusunan anggaran berpengaruh positif dan signifikan pada kinerja aparatur pemerintah.

Hasil penelitian yang berbeda yang didapatkan oleh Bryan dan Locke (1967), Cherrington (1973), Nursidin (2008), Medhayanti dan Suardana (2015) 
menemukan partisipasi penyusunan anggaran mempunyai pengaruh yang tidak signifikan terhadap kinerja manajerial. Hal ini terjadi karena hubungan partisipasi penyusunan anggaran dengan kinerja aparat pemerinah daerah tergantung pada faktor-faktor yang situasional atau variabel kontijensi (Contigency Variable). Perlunya penelitian dengan menggunakan pendekatan kontijensi karena dapat digunakan untuk menguji faktor eksternal yang memengaruhi suatu hubungan (Wiguna dkk., 2017) .Berdasarkan hasil penelitian yang tidak konsisten diatas, penulis tertarik untuk melakukan penelitian dengan judul Pengaruh Partisipasi Penyusunan Anggaran Pada Kinerja Aparat Pemerintah Daerah Dengan Komitmen Organisasi Sebagai Variabel Moderasi.

Peneliti memilih komitmen organisasi sebagai variabel moderasi karena komitmen organisasi didasarkan pada alasan bahwa semakin kuat komitmen organisasi maka akan mempengaruhi peningkatan kinerja para pegawainya. Komitmen organisasi merupakan dorongan dari dalam individu untuk berbuat sesuatu agar dapat menunjang keberhasilan organisasi sesuai dengan tujuan dan lebih mengutamakan kepentingan organisasi dibandingkan dengan kepentingan sendiri (Ayu dan Pradnyantha, 2017). Ketidakjelasan peran dapat mengakibatkan bawahan ragu-ragu dalam melaksanakan kegiatan, yang akhirnya mengurangi komitmen bawahan untuk mencapai tujuan. Untuk menghindarinya, bawahan diikut sertakan dalam mengambil keputusan, misalnya berpartisipasi dalam penyusunan anggaran. Partisipasi anggaran menimbulkan komunikasi antara atasan dan bawahan yang berpartisipasi dan mempunyai kendali dalam pembuatan suatu keputusan (Heinle et al, 2014). Ratna (2015) menjelaskan bahwa teori itu 
sejalan dengan hasil penelitiannya, yang dilakukan pada Lembaga Perkreditan Desa (LPD) di kota Denpasar ditemukan bahwa komitmen organisasi sebagai variabel moderasi mampu memperkuat pengaruh partisipasi penyusunan anggaran terhadap kinerja manajerial. Namum Wati (2013) menunjukkan bahwa komitmen organisasi tidak dapat memperkuat hubungan partisipasi penyusunan anggaran terhadap kinerja aparat pemerintah daerah. Penelitian tersebut juga diperkuat dengan penelitian Ayu dan Pradnyantha (2017) menunjukkan bahwa komitmen organisasi tidak mampu memperkuat pengaruh partisipasi penyusunan anggaran pada kinerja manajerial PT.PLN (Persero) Distribusi Bali.

Alasan penulis memilih Kabupaten Badung sebagai obyek penelitian adalah nilai akuntabilitas kinerja Kabupaten Badung meningkat dalam Laporan Akuntabilitas Kinerja Instansi Kabupaten Badung (LAKIP) menyatakan bahwa kinerja pemerintah Kabupaten Badung tahun 2017 meningkat dari 76,37 menjadi 77,53 dengan predikat BB (sangat baik). Dengan adanya peningkatan kinerja aparat pemerintah Kabupaten Badung, sehingga penelitian ini dilakukan di Kabupaten Badung. Kabupaten Badung merupakan salah satu kabupaten yang terdapat di Provinsi Bali.

Dalam organisasi sektor publik, partisipasi anggaran dan pengukuran kinerja tidak sebatas pada masalah pemakaian anggaran, namun pengukuran kinerja mencakup berbagai aspek yang dapat memberikan informasi yang efisien dan efektif dalam mencapai hasil yang diinginkan kinerja. Kinerja aparat pemerintah merupakan salah satu faktor yang dapat meningkatkan efektivitas organisasi. Partisipasi bawahan dalam penyusunan anggaran dan peran anggaran 
sebagai pengukur kinerja memiliki kaitan yang cukup kuat. Anggaran yang telah ditetapkan berfungsi sebagai perencanaan dan sebagai kriteria kinerja, yaitu anggaran dipakai sebagai suatu sistem pengendalian untuk mengukur kinerja aparat pemerintah. Partisipasi anggaran dapat dinilai sebagai pendekatan aparat pemerintah daerah yang dapat meningkatkan kinerja setiap anggota organisasi sebagai individual karena dengan adanya partisipasi dalam penyusunan anggaran diharapkan setiap aparat pemerintah daerah mampu meningkatkan kinerjanya sesuai dengan target yang telah ditetapkan sebelumnya sesuai dengan pengertian dari teori penetapan tujuan atau goal setting theory.

Penelitian yang dilakukan oleh (Wiguna dkk., 2017), menyatakan bahwa partisipasi penyusunan anggaran berpengaruh positif pada kinerja aparat pemerintah. Ayunda dan Alit (2016) juga mengatakan terdapat pengaruh positif antara partisipasi penyusunan anggaran terhadap kinerja manajerial aparat pemerintah daerah Kabupaten Badung. Tarigan (2015) dan Zein (2016) menyatakan bahwa partisipasi penyusunan anggaran memiliki pengaruh positif dan signifikan terhadap kinerja kinerja manajerial Organisasi Perangkat Daerah (OPD).Variabel partisipasi anggaran juga berpengaruh terhadap kinerja aparat pemerintah dari penelitian Siahaan (2017). Berdasarkan uraian di atas diusulkan hipotesis:

$\mathrm{H}_{1}$ : Partisipasi penyusunan anggaran berpengaruh positif pada kinerja aparat pemerintah daerah.

Komitmen organisasi adalah dorongan dari dalam individu untuk berbuat sesuatu agar dapat menunjang keberhasilan organisasi sesuai dengan tujuan dan lebih mengutamakan kepentingan organisasi dibandingkan dengan kepentingan 
sendiri (Siahaan, 2017). Komitmen yang tinggi menjadikan individu peduli dengan nasib organisasi dan berusaha menjadikan organisasi ke arah yang lebih baik dan partisipasi anggaran membuka peluang bagi bawahan untuk menciptakan kinerja yang baik jika komitmen karyawan terhadap organisasi berada pada tingkat yang tinggi.

Komitmen organisasi yang kuat akan mendorong anggota organisasi berusaha keras mencapai tujuan. Komitmen yang tinggi akan menjadikan individu lebih mementingkan organisasi daripada kepentingan pribadi dan berusaha menjadikan organisasi lebih baik. Aparat pemerintah daerah yang memiliki komitmen organisasi yang tinggi akan menggunakan informasi yang dimiliki untuk membuat anggaran menjadi relatif cepat. Komitmen yang tinggi dari aparat pemerintah daerah akan berdampak pada tanggung jawab terhadap penyusunan anggaran. Hal ini juga didukung oleh penelitian yang dilakukan Asdita dan Asri (2017) yang menyatakan bahwa komitmen organisasi berpengaruh positif pada kinerja SKPD. Siahaan (2017) juga mengatakan partisipasi penyusunan anggaran berpengaruh terhadap kinerja aparat pemerintah yang dimoderasi oleh komitmen organisasi. Dengan adanya komitmen organisasi yang tinggi maka akan mempengaruhi aparat pemerintah daerah untuk bekerja keras dalam mencapai tujuan organisasi. Berdasarkan hasil penelitian yang berkaitan dengan komitmen organisasi, ditentukan bahwa dimensi komitmen organisasi mempunyai pengaruh terhadap penyusunan anggaran dalam meningkatkan kinerja aparat pemerintah. Hipotesis yang diajukan dalam penelitian ini adalah:

$\mathrm{H}_{2}$ : Komitmen organisasi memoderasi pengaruh positif partispasi penyusunan anggaran pada kinerja Aparat Pemerintah Daerah. 


\section{METODE PENELITIAN}

Penelitian ini dilakukan pada 37 Organisasi Perangkat Daerah Kabupaten Badung, Bali. Alasan melakukan penelitian di Pemerintah Daerah Kabupaten Badung karena Kabupaten Badung merupakan organisasi sektor publik dengan anggaran dan realisasi nominal pendapatan daerah tertinggi di Bali.Pemilihan lokasi ini juga karena Kabupaten Badung tahun 2017 mendapatkan predikat BB (sangat baik) dalam LAKIP Kabupaten Badung.

Populasi dalam penelitian ini adalah pejabat yang berwenang dalam penyusunan anggaran pada OrganisasiPerangkatDaerah di Kabupaten Badung. sampel dalam penelitian ini adalah sekretaris, kepala dinas/kepala badan/camat, bagian keuangan, dan bagian perencanaan yang terlibat di dalam penyusunan anggaran. Jumlah sampel yang diambil dari populasi penelitian adalah 148 partisipan yang menjadi responden dalam pengisian kuesioner.

Teknik analisis data yang digunakan untuk menguji hipotesis dalam penelitian ini adalah Moderated Regression Analysis (MRA). Analisis regresi ini merupakan aplikasi khusus regresi linear berganda, dalam persamaan regresinya mengandung unsur interaksi (Ghozali, 2016:233). Penelitian ini menggunakan uji MRA karena dapat menjelaskan pengaruh variabel pemoderasi dalam memperkuat atau memperlemah hubungan antara variabel independen dengan dependen.Rumus ini digunakan untuk mengukur pengaruh variabel independen yaitu partisipasi penyusun anggaran, variabel dependen yaitu kinerja aparat pemerintah daerah dengan variabel moderasi yaitu komitmen organisasi. Rumus yang digunakan sebagai berikut : 
$\mathrm{Y}=\mathrm{a}+\beta_{1} \mathrm{X}_{1}+\beta_{2} \mathrm{X}_{2}+\beta_{3}\left[\left(\mathrm{X}_{1} * \mathrm{X}_{2}\right)\right]+\mathrm{e}$

Keterangan :

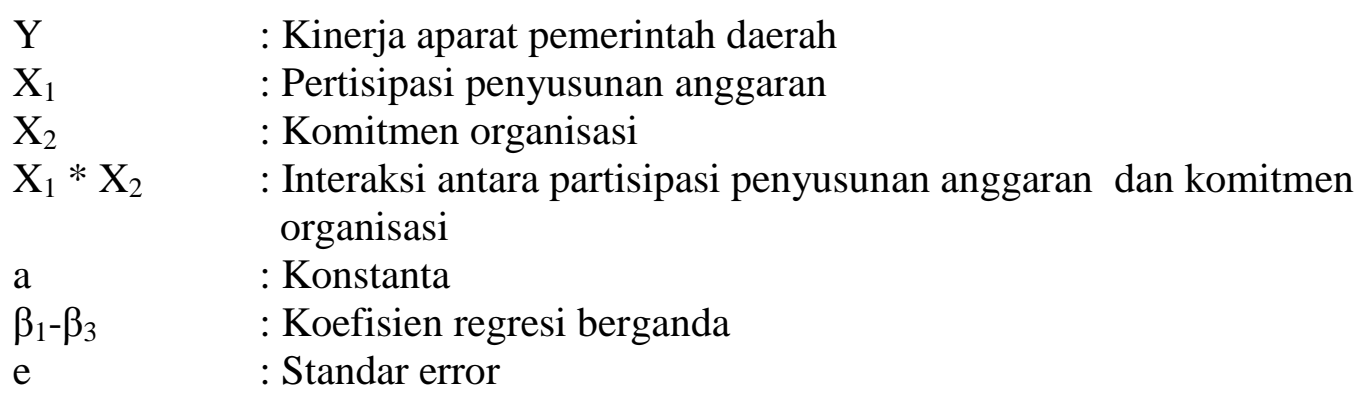

\section{HASIL DAN PEMBAHASAN}

Penelitian ini dilakukan untuk mengetahui faktor-faktor yang mempengaruhi kinerja aparat pemerintah pada Organisasi Perangkat Daerah Kabupaten Badung. Penelitian ini dilakukan pada 37 OPD di Kabupaten Badung. Data dikumpulkan dengan menyebarkan sebanyak empat eksemplar kuesioner pada masing-masing OPD, kuesioner tersebut dikirim langsung oleh peneliti dalam kurun waktu 4 hari yaitu dari tanggal 3 Oktober 2018 sampai 6 Oktober 2018 dan peneliti mengumpulkan kembali dalam kurun waktu 14 hari yaitu dari tanggal 8 Oktober 2018 sampai 21 Oktober 2018. Data penelitian diperoleh dari hasil kuesioner yang telah disebarkan kepada responden yang berjumlah 148 orang. Berikut adalah ringkasan pengiriman dan pengembalian kuesioner pada Tabel 1. 
Tabel 1.

\section{RingkasanPengiriman dan PengembalianKuesioner}

\begin{tabular}{lc}
\hline \multicolumn{1}{c}{ Keterangan } & Jumlah Kuesioner \\
\hline Kuesioner yang disebarkan & 148 \\
Kuesioner yang kembali & 121 \\
Kuesioner yang tidak kembali & 27 \\
Kuesioner yang tidak dapat digunakan & 0 \\
Kuesioner yang digunakan & 121 \\
Tingkat pengembalian yang digunakan & \\
(usable respon rate) $121 / 148 * 100 \%=82 \%$ & \\
\hline Sumber: Data diolah, 2018 &
\end{tabular}

Berdasarkan tabel 1 menunjukkan bahwa kuesioner yang tersebar ke responden sebanyak 148 kuesioner. Jumlah kuesioner yang dikembalikan adalah 121 kuesioner (82\%) sedangkan sebanyak 27 kuesioner tidak kembali karena kesibukan OPD maupun karena hilang. Berdasarkan kondisi tersebut hanyak 121 kuesioner $(82 \%)$ yang masuk dalam kriteria sampel untuk dapat diproses lebih lanjut.

Hasil statistik deskriptif penelitian ini dapat dilihat pada Tabel 2 sebagai berikut.

Tabel 2.

Hasil StatistikDeskriptif

\begin{tabular}{lccccc}
\hline \multicolumn{1}{c}{ Variabel } & N & Min. & Max. & Mean & $\begin{array}{c}\text { Std. } \\
\text { Deviasi }\end{array}$ \\
\hline Partisipasi Penyusunan Anggaran (X1) & 121 & 11 & 20 & 17,72 & 2,038 \\
Komitmen Organisasi (X2) & 121 & 17 & 32 & 27,93 & 3,351 \\
Kinerja Aparat Pemerintah Daerah (Y) & 121 & 13 & 20 & 16,77 & 2,040 \\
\hline
\end{tabular}

Sumber:Data diolah, 2018

Berdasarkan Tabel 2 dapat dilihat bahwa variabel partisipasi penyusunan anggaran (X1) memiliki nilai minimum sebesar 11 dan nilai maksimum sebesar 20 dengan nilai rata-rata sebesar 17,72, jika dibagi dengan 5 item pertanyaan akan menghasilkan nilai sebesar 3,544 yang artinya rata - rata responden memberikan skor 4 untuk item pertanyaan partisipasi penyusunan anggaran. Nilai standar 
deviasi variabel partisipasi penyusunan anggaran adalah sebesar 2,038. Hal ini berarti standar penyimpangan data terhadap nilai rata-ratanya adalah 2,038.

Variabel Komitmen Orgnisasi (X2) memiliki nilai minimum sebesar 17 dan nilai maksimum sebersar 32 dengan nilai rata-rata sebesar 27,93, jika dibagi dengan 8 item pertanyaan akan menghasilkan nilai sebesar 3,491 yang artinya rata - rata responden memberikan skor 3 untuk item pertanyaan komitmen organisasi. Nilai standar deviasi variabel komitmen organisasi adalah sebesar 3,351. Hal ini berarti standar penyimpangan data terhadap nilai rata-ratanya adalah 3,351.

Variabel kinerja aparat pemerintah daerah (Y) memiliki nilai minimum sebesar 13 dan nilai maksimum sebesar 20 dengan nilai rata-rata sebesar 16,77,jika dibagi dengan 5 item pertanyaan akan menghasilkan nilai sebesar 3,354 yang artinya rata - rata responden memberikan skor 3 untuk item pertanyaan kinerja aparat pemerintah daerah.Nilai standar deviasi variabel kinerja aparat pemerintah daerah adalah sebesar 2,070. Hal ini berarti standar penyimpangan data terhadap nilai rata-ratanya adalah 2,070.

Moderated Regression Analysis (MRA) adalah aplikasi dari regresi linier berganda dimana dalam persamaan regresinya mengandung unsure interaksi (perkalian dua atau lebih variable independen). MRA merupakan teknik analisis data yang digunakan untuk mengetahui pengaruh variabel independen terhadap variabel dependennya dan kemampuan variabel pemoderasi dalam memoderasi pengaruh variabel independen terhadap variabel dependennya. Hasil dari analisis MRA dapat dilihat pada Tabel 4 berikut ini. 
Tabel 3.

Hasil Uji MRA

\begin{tabular}{|c|c|c|c|c|c|}
\hline \multirow[b]{2}{*}{ Model } & \multicolumn{2}{|c|}{$\begin{array}{l}\text { Unstandardized } \\
\text { Coefficients }\end{array}$} & \multirow{2}{*}{$\begin{array}{l}\text { Standardized } \\
\text { Coefficients } \\
\text { Beta }\end{array}$} & \multirow[b]{2}{*}{$\mathrm{T}$} & \multirow[b]{2}{*}{ Sig. } \\
\hline & B & $\begin{array}{l}\text { Std. } \\
\text { Error }\end{array}$ & & & \\
\hline (Constant) & 4.442 & .951 & & 4.670 & .000 \\
\hline $\mathrm{X} 1$ & .342 & .052 & .379 & 6.590 & .000 \\
\hline $\mathrm{X} 2$ & .133 & .041 & .182 & 3.205 & .002 \\
\hline X1_X2 & .281 & .049 & .360 & 5.756 & .000 \\
\hline F hitung & $: 132,246$ & & & & \\
\hline Signifikansi F & $: 0,000$ & & & & \\
\hline Adjusted R Square & $: 0,766$ & & & & \\
\hline
\end{tabular}

Berdasarkan perhitungan uji MRA di atas, maka didapatkan hasil persamaan regresi sebagai berikut:

$$
\mathrm{Y}=4,442+0,342 \mathrm{X}_{1}+0,133 \mathrm{X}_{2}+0,281 \mathrm{X}_{1} \mathrm{X}_{2}
$$

Konstanta sebesar 4442 memiliki arti apabila partisipasi penyusunan anggaran (X1), komitmen organisasi (X2) sama dengan nol, maka nilai kinerja aparat pemerintah daerah (Y) meningkat sebesar 4,442 satuan

Nilai koefisien $\beta_{1}=0,342$ menunjukkan partisipasi penyusunan anggaran (X1) bernilai positif, hal ini berarti partisipasi penyusunan anggaran mempunyai pengaruh positif terhadap kinerja aparat pemerintah daerah, bila partisipasi penyusunan anggaran meningkat satu satuan akan cenderung meningkatkan kinerja aparat pemerintah daerah dengan asumsi variabel lainnya sama dengan nol.

Nilai koefisien $\beta_{2}=0,133$ menunjukkan komitmen organisasi (X2) bernilai positif, hal ini berarti komitmen organisasi mempunyai pengaruh positif terhadap kinerja aparat pemerintah daerah, bila komitmen organisasi meningkat satu satuan akan cenderung meningkatnya kinerja aparat pemerintah daerah dengan asumsi variabel lainnya sama dengan nol. 
Nilai koefisien $\beta_{3}=0,281$ menunjukan bila nilai interaksi antara partisipasi penyusunan anggaran dengan komitmen organisasi (X1X2) bertambah satu satuan, maka nilai dari kinerja aparat pemerintah daerah(Y) akan mengalami peningkatan sebesar 0.281 satuan dengan asumsi variabel lainnya konstan.

Koefisien determinasi mengukur seberapa jauh kemapuan model dalam menerapkan variabel-variabel dependen. Pada penelitian ini, besarnya nilai Adjusted R square adalah sebesar 0,766 yang artinya sebesar 76,6\% variasi kinerja aparat pemerintah daerah dipengaruhi oleh partisipasi penyusunan anggaran, komitmen organisasi, dan interaksi antara penyusunan anggaran dengan komitmen organisasi, sedangkan sisanya sebesar 23,4 persen dipengaruhi oleh faktor lain yang tidak dimasukkan ke dalam model penelitian.

Uji F pada dasarnya menunjukkan apakah semua variabel bebas yang dimasukkan dalam model mempunyai pengaruh secara bersama-sama pada variabel dependen. Berdasarkan hasil uji, nilai signifikansi $\mathrm{F}$ adalah sebesar 0,000 yang lebih kecil dari $0,05(\mathrm{~F}<\alpha)$ yang berarti variabel bebasyaitu partisipasi penyusunan anggaran $\left(\mathrm{X}_{1}\right)$, komitmen organisasi $\left(\mathrm{X}_{2}\right)$, serta interaksi antara penyusunan anggaran dengan komitmen organisasi (X1*X2) berpengaruh signifikan secara serempak atau bersama-sama terhadap variabel terikat yaitu kinerja aparat pemerintah daerah $(\mathrm{Y})$.

Uji t digunakan untuk mengetahui pengaruh variabel independen secara parsial terhadap variabel dependen dan untuk mengetahui apakah variabel pemoderasi mampu memoderasi pengaruh variabel independen terhadap variabel dependennya. 
Pada Tabel 4 dapat dilihat bahwa variabel partisipasi penyusunan anggaran memiliki nilai koefisien beta positif sebesar 0,342 dengan nilai signifikansi sebesar 0,000. Nilai koefisien beta $>0$ dan nilai signifikansi $<0,05$ mengindikasikan bahwa partisipasi penyusunanan anggaran berpengaruh positif dan signifikan terhadap kinerja apparat pemerintah daerah. Dengan demikian, H1 diterima.

Pada Tabel 4 dapat dilihat bahwa variabel komitmen organisasi memiliki nilai koefisien beta positif sebesar 0,281 dengan nilai signifikansi sebesar 0,000 Nilai koefisien beta $>0$ dan nilai signifikansi $<0,05$ mengindikasikan bahwa komitmen organisasi mampu memoderasi pengaruh partisipasi penyusunan anggaran terhadap kinerja aparat pemerintah daerah secara positif. Dengan demikian, $\mathrm{H} 2$ diterima.

Partisipasi Penyusunan Anggaran didapat melalui perhitungan rata-rata statistik dari masing-masing pernyataan variabel partisipasi penyusunan anggaran yang dikembangkan oleh Purmita dan Adi (2014). Tabel 5memperlihatkan hasil statistik deskriptif partisipasi penyusunan anggaran sebagai berikut:

Tabel 4.

Partisipasi Penyusunan Anggaran

\begin{tabular}{|c|c|}
\hline Indikator & Mean \\
\hline $\begin{array}{l}\text { Partisipasi penyusunan anggaran } \\
\text { Indikator: }\end{array}$ & 3,73 \\
\hline 1) Keterlibatan dalam penyusunan anggaran & 3,07 \\
\hline 2) Frekuensi saran yang diberikan & 3,14 \\
\hline Indikator & Mean \\
\hline 3) Besarnya pengaruh terhadap penetapan anggaran akhir & 3,07 \\
\hline 4) Kontribusi dalam proses penganggaran & 3,23 \\
\hline 5) Frekuensi atasan meminta pendapat & 3,14 \\
\hline
\end{tabular}

Sumber: Data diolah, 2018

Berdasarkan tabel 4 rata-rata variabel partisipasi penyusunan anggaran mendapat hasil perhitungan 3,73. Dengan rata-rata 3,73 tersebut menunjukkan 
bahwa pelaksanaan partisipasi dalam penyusunan anggaran pada kinerja aparat pemerintah daerah di Kabupaten Badung sudah berjalan efektif. Masing-masing indikator partisipasi penyusunan anggaran telah berjalan dengan efektif pula dimana indikator kontribusi dalam proses penganggaran merupakan rata-rata perhitungan dengan hasil tertinggi dibanding indikator lainnya, sedangkan keterlibatan dalam penyusunan anggaran dan besarnya pengaruh terhadap penetapan anggaran akhir merupakan nilai yang terendah.

Meskipun telah masuk dalam kategori efektif, namun perlu untuk dilakukan perbaikan terutama pada indikator keterlibatan dalam penyusunan anggaran dan besarnya pengaruh terhadap penetapan anggaran sebagai skor ratarata terendah. Aparat pemerintah daerah khususnya di OPD Kabupaten Badung diharapkan lebih aktif terlibat dan memberikan pendapat dalam proses penyusunan anggaran. Aparat pemerintah yang terlibat dalam pengambilan keputusan akan termotivasi dalam situasi kelompok atau organisasi karena diberi kesempatan untuk mewujudkan inisiatif dan daya kreatifitas, tujuan bersama akan lebih mudah tercapai sehingga kinerja aparat pemerintah di OPD Kabupaten Badung akan meningkat.

Komitmen Organisasi didapat melalui perhitungan rata-rata statistik dari masing-masing pernyataan variabel komitmen organisasi yang mengacu pada kuesioner penelitian Ratna (2015). Tabel 5 memperlihatkan hasil statistik deskriptif komitmen organisasi sebagai berikut: 
Tabel 5.

Komitmen Organisasi

\begin{tabular}{|c|c|}
\hline Indikator & Mean \\
\hline Komitmen Organisasi & 3,73 \\
\hline Indikator: & \\
\hline 1) Kebanggaan bekerja & 2.84 \\
\hline 2) Usaha untuk menyukseskan organisasi & 3.34 \\
\hline 3) Kesediaan menerima tugas & 3.14 \\
\hline 4) Loyalitas terhadap organiasasi & 3.14 \\
\hline 5) Kebanggaan menjadi bagian dari organisasi & 3.23 \\
\hline 6) Keterikatan terhadap organisasi & 2.94 \\
\hline 7) Anggapan bahwa organisasi adalah organisasi yang terbaik & 3.14 \\
\hline 8) Kepedulian terhadap organisasi & 3,00 \\
\hline
\end{tabular}

Sumber: Data diolah, 2018

Berdasarkan tabel 5 rata-rata variabel komitmen organisasi mendapat hasil perhitungan 3,73 . Dengan rata-rata 3,73 tersebut menunjukkan bahwa komitmen organisasi yang dimiliki aparat pemerintah dalam penyusunan anggaran di OPD Kabupaten Badung sudah berjalan efektif. Masing-masing indikator komitmen organisasi telah berjalan dengan efektif pula dimana indikator usaha untuk menyukseskan organisasi merupakan rata-rata perhitungan dengan hasil tertinggi dibanding indikator lainnya, sedangkan kebanggaan bekerja dan keterikatan terhadap organisasi merupakan nilai yang terendah.

Meskipun telah masuk dalam kategori efektif, namun perlu untuk dilakukan perbaikan terutama pada indikator kebanggaan bekerja dan keterikatan terhadap organisasi sebagai skor rata-rata terendah. Aparat pemerintah daerah khususnya di OPD Kabupaten Badung diharapkan lebih bangga dengan pekerjaan yang dilakukan yang menjadi bagian organisasi dan lebih merasa diri bagian dari OPD di Kabupaten Badung, karena dengan aparat pemerintah yang memiliki perasaan bangga bekerja dan keterikatan terhadap organisasi akan meningkatkan komitmen organisasi yang dimiliki. Komitmen organisasi yang tinggi dari aparat 
pemerintah daerah akan berdampak pada tanggung jawab terhadap penyusunan anggaran yang akan mempengaruhi kinerjanya.

Kinerja aparat pemerintah daerah didapat melalui perhitungan rata-rata statistik dari masing-masing pernyataan variabel kinerja aparat pemerintah yang mengacu pada kuesioner penelitian Ratna (2015). Tabel 6 memperlihatkan hasil statistik deskriptif kinerja aparat pemerintah daerah sebagai berikut:

Tabel 6.

Kinerja Aparat Pemerintah Daerah

\begin{tabular}{lc}
\hline \multicolumn{1}{c}{ Indikator } & Mean \\
\hline Kinerja Aparat Pemerintah Daerah & 3,49 \\
Indikator: & 1,00 \\
1) Menjalankan fungsi pengkoordinasian dengan saling bertukar & 1,00 \\
informasi & 3,14 \\
2) Menjalankan fungsi perencanaan dengan cara ikut berperan serta & 3,00 \\
3) Menjalankan fungsi investigasi dengan cara mengumpulkan & 3,07 \\
4) Selalu berusaha menyelesaikan pekerjaan lebih cepat dari waktunya & \\
5) Hasil pekerjaan dari individu tersebut menentukan kelangsungan & \\
\hline hidup organisasi &
\end{tabular}

Berdasarkan tabel 6 rata-rata variabel kinerja aparat pemerintah daerah mendapat hasil perhitungan 3,49. Dengan rata-rata 3,49 tersebut menunjukkan bahwa kinerja aparat pemerintah yang dimiliki aparat pemerintah dalam penyusunan anggaran di OPD Kabupaten Badung sudah berjalan efektif. Masingmasing indikator kinerja aparat pemerinta daerah telah berjalan dengan efektif pula dimana indikator menjalankan fungsi investigasi dengan cara mengumpulkan informasi merupakan rata-rata perhitungan dengan hasil tertinggi dibanding indikator lainnya, sedangkan menjalankan fungsi pengkoordinasian dengan saling bertukar informasi dan menjalankan fungsi perencanaan dengan cara ikut berperan serta merupakan nilai yang terendah. 
Meskipun telah masuk dalam kategori efektif, namun perlu untuk dilakukan perbaikan terutama pada indikator pengkoordinasian dan perencanaan sebagai skor rata-rata terendah. Aparat pemerintah daerah diharapkan meningkatkan pertukaran informasi dan berperan serta dalam partisipasi dalam penyusunan anggaran. Pertukaran informasi antara atasan dan bawahan akan menghasilkan informasi yang efektif dan keikutsertaan berbagai pihak, baik atasan maupun bawahan dalam penyusunan anggaran dapat mendorong moral kerja yang tinggi. Dimana para aparat pemerintah akan berusaha menciptakan anggaran yang sesuai dengan standar atau kondisi yang diinginkan dimasa depan sehingga kinerja suatu organisasi dapat ditingkatkan.

Hasil penelitian menunjukkan bahwa nilai koefisien partisipasi penyusunan anggaran $\left(\mathrm{X}_{1}\right)$ sebesar 0,342 dengan tingkat signifikansi 0,000 yang nilainya lebih kecil dari taraf nyata yaitu 0,05 . Hal ini menunjukkan bahwa variabel partisipasi penyusunan anggaran berpengaruh positif pada kinerja aparat pemerintah daerah, maka (H1) diterima.

Pengaruh positif tersebut berarti semakin tinggi partisipasi penyusunan anggaran maka semakin tinggi kinerja aparat pemerintah daerah. Kinerja aparat pemerintah merupakan salah satu faktor yang dapat meningkatkan efektivitas organisasi. Partisipasi bawahan dalam penyusunan anggaran dan peran anggaran sebagai pengukur kinerja memiliki kaitan yang cukup kuat. Anggaran yang telah ditetapkan berfungsi sebagai perencanaan dan sebagai kriteria kinerja, yaitu anggaran dipakai sebagai suatu sistem pengendalian untuk mengukur kinerja aparat pemerintah daerah. 
Hal ini didukung oleh penelitian yang dilakukan oleh Wiguna dkk., (2017), Ayunda dan Alit (2016), Saraswati(2015), dan Siahaan (2017) yang menemukan bahwa partisipasi penyusunan anggaran berpengaruh positif pada kinerja aparat pemerintah daerah. Sedangkan tidak konsisten dengan penelitian yang dilakukan oleh Karsam (2015),Medhayanti dan Suardana(2015) menemukan partisipasi penyusunan anggaran mempunyai pengaruh yang tidak signifikan terhadap kinerja manajerial.

Hasil penelitian menunjukkan bahwa nilai koefisien interaksi partisipasi penyusunan anggaran dengan komitmen organisasi $\left(\mathrm{X}_{1} \mathrm{X}_{2}\right)$ sebesar 0,281 dengan tingkat signifikansi sebesar 0,000 yang nilainya lebih kecil dari taraf nyata yaitu 0,05. Hal ini berarti bahwa variabel komitmen organisasi mampu memoderasi pengaruh partisipasi penyusunan anggaran pada kinerja aparat pemerintah daerah dengan arah signifikan positif sehingga $\mathrm{H}_{2}$ diterima. Nilai positif koefisien interaksi partisipasi penyusunan anggaran dengan komitmen organisasi artinya komitmen organisasi dapat memperkuat pengaruh partisipasi penyusunan anggaran pada kinerja aparat pemerintah daerah.

Tingkat komitmen organisasi yang tinggi atau rendah dalam melaksanakan proses penyusunan anggaran dapat memengaruhi kinerja. Komitmen organisasi yang kuat akan mendorong anggota organisasi berusaha keras mencapai tujuan.Aparat pemerintah daerah yang memiliki komitmen organisasi yang tinggi akan menggunakan informasi yang dimiliki untuk membuat anggaran menjadi relatif cepat. Komitmen yang tinggi dari aparat pemerintah daerah akan berdampak pada tanggung jawab terhadap penyusunan anggaran. 
Hal ini juga didukung oleh penelitian yang dilakukan Asdita dan Asri (2017), Siahaan (2017) yang menyatakan bahwa partisipasi penyusunan anggaranberpengaruh terhadap kinerja aparat pemerintah yang dimoderasi oleh komitmen organisasi. Dengan adanya komitmen organisasi yang tinggi maka akan mempengaruhi aparat pemerintah daerah untuk bekerja keras dalam mencapai tujuan organisasi. Berbeda dengan penelitian yang dilakukan olehWati (2013) dan Mike (2017) menunjukkan bahwa komitmen organisasi tidak dapat memperkuat hubungan partisipasi penyusunan anggaran terhadap kinerja aparat pemerintah daerah.

Hasil penelitian ini diharapkan dapat memberikan tambahan informasi mengenai pengaruh partisipasi penyusunan anggaran pada kinerja aparat pemerintah daerah. Selain itu hasil penelitian ini mengkonfirmasi bahwa variabel komitmen organisasi dapat memperkuat hubungan partisipasi penyusunan anggaran pada kinerja aparat pemerintah daerah, sehingga dengan adanya komitmen organisasi yang tinggi dalam partisipasi penyusunan anggaran diharapkan setiap aparat pemerintah daerah mampu meningkatkan kinerjanya sesuai dengan target yang telah ditetapkan sebelumnya sesuai dengan pengertian dari teori penetapan tujuan atau goal setting theory.

Hasil penelitian ini diharapkan mampu memberikan referensi, masukan dan tambahan informasi bagi pihak-pihak yang terkait dalam penyusunan anggaran pada Organisasi Perangkat Daerah Kabupaten Badung dalam mengambil keputusan dan menentukan kebijakan di masa yang akan datang 
terkait penyusunan anggaran sehingga nantinya dapat meningkatkan kinerja aparat pemerintah daerah di Kabupaten Badung.

\section{SIMPULAN}

Partisipasi penyusunan anggaran berpengaruh positif pada kinerja aparat pemerintah daerah. Hal ini bermakna semakin tinggi dari tingkat partisipasi penyusunan anggaran maka semakin tinggi tingkat kinerja dari aparat pemerintah daerah. Hal ini karena partisipasi dalam penyusunan anggaran dapat dinilai sebagai pendekatan aparat pemerintah daerah yang dapat meningkatkan kinerja setiap anggota organisasi sebagai individual karena dengan adanya partisipasi dalam penyusunan anggaran diharapkan setiap aparat pemerintah daerah mampu meningkatkan kinerjanya sesuai dengan target yang telah ditetapkan sebelumnya

Komitmen organisasi memperkuat pengaruh partisipasi penyusunan anggaran pada kinerja aparat pemerintah daerah. Hal tersebut memiliki arti bahwa komitmen organisasi dapat memperkuat pengaruh partisipasi penyusunan anggaran pada kinerja aparat pemerintah daerah. Adanya partisipasi dalam penyusunan anggaran yang dipengaruhi oleh komitmen organisasi yang tinggi akan meningkatkan kinerja aparat pemerintah daerah.

Aparat pemerintah daerah di OPD Kabupaten Badung diharapkan lebih aktif terlibat dan memberikan pendapat dalam proses penyusunan anggaran. Aparat pemerintah yang terlibat dalam pengambilan keputusan akan termotivasi dalam situasi kelompok atau organisasi karena diberi kesempatan untuk mewujudkan 
inisiatif dan daya kreatifitas, tujuan bersama akan lebih mudah tercapai sehingga kinerja aparat pemerintah di OPD Kabupaten Badung akan meningkat.

Aparat pemerintah daerah di OPD Kabupaten Badung diharapkan lebih bangga dengan pekerjaan yang dilakukan yang menjadi bagian organisasi dan lebih merasa diri bagian dari OPD di Kabupaten Badung, karena dengan aparat pemerintah yang memiliki perasaan bangga bekerja dan keterikatan terhadap organisasi akan meningkatkan komitmen organisasi yang dimiliki. Komitmen organisasi yang tinggi dari aparat pemerintah daerah akan berdampak pada tanggung jawab terhadap penyusunan anggaran yang akan mempengaruhi kinerjanya.

Aparat pemerintah daerah di OPD Kabupaten Badung diharapkan lebih bangga dengan pekerjaan yang dilakukan yang menjadi bagian organisasi dan lebih merasa diri bagian dari OPD di Kabupaten Badung, karena dengan aparat pemerintah yang memiliki perasaan bangga bekerja dan keterikatan terhadap organisasi akan meningkatkan komitmen organisasi yang dimiliki. Komitmen organisasi yang tinggi dari aparat pemerintah daerah akan berdampak pada tanggung jawab terhadap penyusunan anggaran yang akan mempengaruhi kinerjanya.

\section{REFERENSI}

Asdita adi, I. W., Sadha Suardikha, I. M., \& Asri Dwija Putri, I. G. A. . (2017). Pengaruh Komitmen Organisasi, Budaya Organisasi dan Kepuasan Pengguna SIMDA Pada Kinerja Satuan Kerja Perangkat Daerah. E-Jurnal Ekonomi Dan Bisnis Universitas Udayana, 6(6), 2587-2616.

Ayunda Ratna Mentari, N. G., \& Alit Suardana, K. (2016). Kepuasan Kerja 
Sebagai Moderasi Pengaruh Partisipasi Penyusunan Anggaran Terhadap Kinerja Manajerial Aparat Pemerintah Daerah. E-Jurnal Akuntansi Universitas Udayana, 17.1, 509-536.

Brownell, P. 1982b. A Field Study Examination of Budgetary Participation and Locus of Control. The Accounting Review, Vol. L. VII, No.4 pp. 766-777.

Brownell, P. 1982b. A Field Study Examination of Budgetary Participation and Locus of Control. The Accounting Review, Vol. L. VII, No.4 pp. 766-777.

Bryan. J, dan E. A. Locke. 1967, Goal Setting as a Means of Increasing Motivation, The of Applied Psycology, pp: 274-277.

Hansen, Don R, dan Maryanne M. Mowen. 2011. Akuntansi Manajerial. Buku 1 Edisi 8. Jakarta: Salemba Empat.

Heinle, Mirko S. , Nicholas Ross, dan Richard E. Saouma. 2014. A Theory of Participative Budgeting. The Accounting Review, 89()3, pp: 1025-1050.

Karsam, 2015. Effects of Budget Emphasis and Motivation on the Reletionship between Participstive Budgeting and Budgetary Slack and the impact on the Managerial Perfomarce. Reseach Journal of Financiance Accounting. Vol.6 No1.

Kenis, I. 1979. Effect on Budgetary Goal Characteristic on Managerial Attitudes And Performance. The Accounting Review. Vol.LIV, No.4, pp, 707-721.

Locke, E. A. 1968. Toward A Theory of Task Motivation and Incentives. Organizational Behavior and Humas Performance, 3(2), pp: 157-189.

Mardiasmo., 2013, Akuntansi Sektor Publik, Yogyakarta: ANDI

Medhayanti, N. P., \& Suardana, K. A. (2015). Pengaruh Partisipasi Anggaran Terhadap Kinerja Manajerial dengan Self Efficacy, Desentralisasi, dan Budaya Organisasi Sebagai Variabel Pemoderasi. E-Jurnal Akuntansi Universitas Udayana, 11(1), 155-170.

Mirda Yanti, N. W., \& Sari, M. M. R. (2016) Asimetri Informasi Sebagai Pemoderasi Pengaruh Partisipasi Penganggaran dan Kejelasan Sasaran Anggaran Pada Senjangan Anggaran. E-Jurnal Akuntansi Universitas Udayana, 15(1), 257-285.

Mulyadi. 2001. Akuntansi Manajemen: Konsep, Manfaat dan Rekayasa. Jakarta: Salemba Empat. 
Nafarin, M. 2013. Penganggaran Perusahaan. Edisi ketiga. Jakarta: Salemba Empat

Nursidin, M. 2008. Pengaruh Anggaran Partisipatif Terhadap Kinerja Manajerial Melalui Kesenjangan Anggaran dan Motivasi Kerja pada PT. (Persero) Pelabuhan Indonesia-Medan. Tesis. Sekolah Pasca Sarjana Universitas Sumatra Utara

Pariono, A., \& Wirawati, N. G. P. (2018). Pengaruh Partisipasi Penyusunan Anggaran, Komitmen Organisasi, dan LOC Pada Kinerja Manajerial di PDAM Tabanan. E-Jurnal Akuntansi Universitas Udayana, 23, 21182144.

PP Nomor 58 Tahun 2005 tentang Pengelolaan Keuangan Daerah

Purba Dianthi, I. A. G., \& Wirakusuma, M. G. (2017). Pengaruh Partisipasi Penganggaran, Asimetri Informasi, Budaya Organisasi dan Komitmen Organisasi Pada Senjangan Anggaran. E-Jurnal Akuntansi Universitas Udayana, 18(2), 874-901.

Purmita Dewi, N., \& Adi Erawati, N. M. (2014). Pengaruh Partisipasi Pengangaran, Informasi Asimetri, Penekanan Anggaran dan Komitmen Organisasi Pada Senjangan Anggaran. E-Jurnal Akuntansi Universitas Udayana, 9(2), 476-486.

Ratna, D. P. (2015). Pengaruh PAertisipasi Penganggaran Pada Kinerja Manajerial Di LPD Kota Denpasar. E-Jurnal Akuntansi Universitas Udayana, 11(2), 595-610.

Robbins, Stephen P. Dan Timothi A. Judge. 2008. Perilaku Organisasi. Jakarta:Salemba Empat.

Rokhman, M. T. N. (2017). Improving Managerial Performance Through Participation Role of Budget Preparation; A Theoretical and Empirical Overview. journal of Economics and Finance. 8(1), 39-43.

Saraswati, G. P. (2015). Pengaruh Partisipasi Penyusunan Anggaran Terhadap Kinerja Manajerial Dengan Job Revelant Information Sebagai Variabel Moderating. Jurnal Nominal, 4(2), 136-147.

Siahaan, C. A., Savitri, E., \& A, A. A. (2017). Pengaruh Partisipasi Penyusunan Anggaran dan Kejelasan Sasaran Anggaran Terhadap Kinerja Aparat Pemerintah Daerah Dengan Kepuasan Kerja dan Komitmen Organisasi Sebagai Variabel Moderating. JOM Fekon, 4(1), 1351-1363. 
Tarigan, J. (2015). The Influence of Budgeting Participation on Managerial Performance in Service Companies: An evidence from Indonesia. Journal of Accounting and Finance, 15(8), 95-105.

Pengaruh Partisipasi Penyusun Anggaran Terhadap Kinerja Manajerial: Komitmen Organisasi dan Persepsi inovasi sebagai variabel intervening Studi Empiris pada Satuan Kerja Instansi Vertikal Wilayah Pembayaran Kantor Pelayanan Perbendaharaan Negara Samp. Diponegoro Journal of Accounting, 2(3), 1-12.

PP No 8 tahun 2006 tentang pelaporan keuangan dan kinerja instansi pemerintah UU 23 Tahun 2014 tentang Pemerintah Daerah

Wati, E. (2013). Pengaruh Budaya Organisasi dan Komitmen Organisasi Terhadap Hubungan Partisipasi Penyusunan Anggaran Dengan Kinerja Pemerintah Daerah. Jurnal Fakultas Ekonomi Universitas Negeri: Padang, 1-24.

Widyawati, I. A., \& Maria M, R. S. (2017). Pengaruh Komitmen Organisasi Pada Kinerja Manajerial Dengan Locus Of Control Sebagai Variabel Moderasi. E-Jurnal Akuntansi Universitas Udayana, 19(1), 311-336.

Widya Astuti, N. P., \& Mahaendra Yasa, I. N. (2018). The Effect of Human Resource Quality and Budgeting Participation on Organizational Culture and Organizational Performance. Quantitative Economics Research, 1(1), $39-46$.

Wiguna, L. Y. P., Sukartha, I. M., \& Putra Astika, I. B. (2017). Pengaruh Partisipasi Penyusunan Anggaran Pada Kinerja Aparat Pemerintah Daerah Dengan Budaya Organisasi, Motivasi, dan gaya Kepemimpinan Sebagai Variabel Moderating. E-Jurnal Akuntansi Universitas Udayana, 8(6), 3041-3070.

Zein, M. (2016). Pengaruh Parisipasi Penyusunan Anggaran dan Kejelasan Sasaran Anggaran Terhadap Kinerja Aparat Pemerintah Daerah Kabupaten Siak dengan Komitmen Organisasi sebagai Variabel Moderating.JOM Fekon.3(1), 1550-1565. 